\title{
ANALISIS PERILAKU KONSUMEN TERHADAP KEPUTUSAN PEMBELIAN KOPI DI KALIMERA COFFEE BAR SALATIGA
}

\author{
ANALYSIS OF CONSUMER BEHAVIOR TOWARDS COFFEE PURCHASING \\ DECISIONS IN KALIMERA COFFEE BAR SALATIGA
}

\author{
JANEFFER FLAURENCE TAREHY*, BAYU NUSWANTARA \\ Fakultas Pertanian dan Bisnis, Universitas Kristen Satya Wacana - Salatiga \\ *E-mail: 522016079@student.uksw.edu
}

\begin{abstract}
ABSTRAK
Konsumsi kopi yang terus meningkat setiap tahunnya telah menjadi suatu trend yang baru bagi masyarakat Indonesia. Sebagian besar masyarakat telah menganggap bahwa mengonsumsi kopi tidak lagi sekedar sebagai minuman pelengkap saja namun menjadikan kopi sebagai minuman pokok seharihari khususnya bagi masyarakat yang telah kencanduan mengonsumsi minuman ini. Penelitian ini bertujuan untuk mengetahui karakteristik konsumen, menganalisis indeks kepuasan konsumen, dan dan menganalisis atribut-atribut produk kopi yang dianggap penting oleh konsumen. Penelitian dilakukan di Kalimera Coffee Bar Salatiga. Jenis penelitian yang digunakan adalah kuantitatif. Teknik pengambilan sampel yang digunakan adalah convenience sampling dengan jumlah sampel ditetapkan sebanyak 40 responden. Penelitian ini menggunakan 8 atribut produk, yaitu rasa, varian rasa, aroma, ukuran/ volume isi, tampilan fisik, kualitas pelayanan, kenyamanan tempat dan harga produk. Pengumpulan data dilakukan dengan wawancara, kuesioner yang diisi secara online, studi pustaka, dan dokumentasi. Teknik analisis data yang digunakan yaitu analisis deskriptif, Customer Satisfaction Index (CSI), dan Importance and Performance Analysis (IPA). Hasil penelitian menunjukkan karakteristik konsumen usia 16 sampai dengan 40 tahun, berstatus belum menikah dengan tingkat pendidikan SMA dan Diploma/ Sarjana (S1, S2, S3), didominasi oleh pelajar dan mahasiswa, dan sisanya bekerja sebagai pegawai swasta, PNS/ ABRI, wiraswasta dan freelancer, memiliki pendapatan per bulan mulai dari dibawah 2,5 juta rupiah sampai diatas 5 juta rupiah. Indeks kepuasan konsumen yang di peroleh berada pada klasifikasi sangat puas dengan persentase 87,39 persen. Atribut produk yang perlu dipertahankan adalah rasa, kualitas pelayanan dan kenyamanan tempat.
\end{abstract}

Kata Kunci: perilaku konsumen, kopi, customer satisfaction index, importance and performance analysis.

\begin{abstract}
ABSTRACK
Coffee consumption which continues to increase every year has become a new trend for the Indonesian people. Most people have considered that consuming coffee is no longer just a complementary drink but makes coffee as a daily staple drink, especially for people who are addicted to consuming this drink. This study aims to determine the characteristics of consumers, analyze the consumer satisfaction index, and analyze the attributes of coffee products that are considered important by consumers. The research was conducted at Kalimera Coffee Bar Salatiga. The type of research used is quantitative. The sampling technique used was convenience sampling with a sample size of 40 respondents. This study uses 8 product attributes, namely taste, flavor variant, aroma, size/volume of content, physical appearance, service quality, place comfort and product price. Data was collected by means of interviews, online questionnaires, literature studies, and documentation. Data analysis techniques used are descriptive analysis, Customer Satisfaction Index (CSI), and Importance and Performance Analysis (IPA). The results showed the characteristics of consumers aged 16 to 40 years, unmarried status with high school education level and Diploma/Bachelor (S1, S2, S3), dominated by students and college students, and the rest worked as private employees, civil servants/ABRI, self-employed and freelancer, has a monthly income ranging from below 2.5 million rupiah to above 5 million rupiah. The consumer satisfaction index obtained is in the very satisfied
\end{abstract}


classification with a percentage of 87.39 percent. Product attributes that need to be maintained are taste, quality of service and comfort of the place.

Keywords: consumer behavior, coffee, customer satisfaction index, importance and performance analysis.

\section{PENDAHULUAN}

Kopi merupakan salah satu komoditas tanaman perkebunan yang bernilai ekonomis lebih tinggi dari jenis tanaman perkebunan lainnya, dan mampu menjadi sumber penghasilan bagi satu setengah juta jiwa petani kopi di Indonesia. Selain sebagai sumber penghasilan bagi rakyat, kopi juga memiliki peran penting sebagai komoditas ekspor andalan dan sebagai sumber pendapatan devisa Negara (Raharjo, 2012).
Konsumsi kopi di Indonesia telah meningkat dengan cukup pesat dari tahuntahun sebelumnya. Hal ini diprediksi akan terus mengalami peningkatan seiring meningkatnya pendapatan masyarakat kelas menengah dan perubahan gaya hidup. Di bawah ini data mengenai konsumsi kopi di Indonesia lima tahun terakhir terhadap pertumbuhan penduduk serta prediksi kenaikannya.

\section{Tabel 1. Proyeksi Konsumsi Kopi di Indonesia}

\begin{tabular}{ccccc}
\hline Tahun & $\begin{array}{c}\text { Konsumsi } \\
(\text { Kg/kap/thn) }\end{array}$ & $\begin{array}{c}\text { Jumlah } \\
\text { Penduduk (000 } \\
\text { orang) }\end{array}$ & $\begin{array}{c}\text { Konsumsi } \\
\text { Nasional (Ton) }\end{array}$ & $\begin{array}{c}\text { Pertumbuhan } \\
(\boldsymbol{\%})\end{array}$ \\
\hline $\left.2016^{* *}\right)$ & 1,168 & 258.705 & 302.176 & \\
$\left.2017^{* *}\right)$ & 1,162 & 261.891 & 304.231 & 0,68 \\
$\left.2018^{* *}\right)$ & 1,155 & 265.015 & 306.183 & 0,64 \\
$\left.2019^{* *}\right)$ & 1,149 & 267.974 & 307.915 & 0,57 \\
$\left.2020^{* *}\right)$ & 1,143 & 271.066 & 309.771 & 0,60 \\
\hline Total Pertumbuhan & & & 2,49
\end{tabular}

Keterangan: **) Angka Proyeksi Pusdatin

Sumber: Pusat Data dan Sistem Informasi Pertanian (2016)

Berdasarkan tabel 1.1, diperoleh data yang memprediksikan jumlah konsumsi kopi dalam kurun waktu yang mengalami peningkatan setiap tahunnya dan diperkirakan akan terus meningkat. Hal ini memberikan peluang besar di bidang agribisnis terutama bagi para pelaku usaha kedai kopi atau coffee shop.

Konsumsi kopi yang terus meningkat setiap tahunnya telah menjadi suatu trend yang baru bagi masyarakat Indonesia. Sebagian besar masyarakat telah 
menganggap bahwa mengonsumsi kopi tidak lagi sekedar sebagai minuman pelengkap saja namun menjadikan kopi sebagai minuman pokok sehari-hari khususnya bagi masyarakat yang telah kencanduan mengonsumsi minuman ini. Permintaan akan kopi yang terus meningkat ini memancing lahirnya mermacam-macam brand, café dan juga coffee shop di kota-kota besar. Dalam hal budaya mengonsumsi kopi ini umumnya dilakukan oleh masyarakat di kafe dan coffee shop bagi masyarakat di kota-kota besar, dan di kedai atau warung kopi bagi masyarakat di desa atau kota-kota kecil (Kurniawan, 2017).

Munculnya berbagai coffee shop atau kedai kopi menjadikan konsumen mempunyai banyak pilihan terhadap coffee shop yang ada. Hal ini akan menimbulkan sebuah ketertarikan dari konsumen untuk memilih sebuah coffee shop. Dalam rangka menganalisis perilaku konsumen, ada beberapa faktor yang berpengaruh pada perilaku konsumen. Faktor-faktor tersebut diantaranya faktor budaya, faktor sosial, faktor pribadi dan faktor psikologis (Kotler dan Susanto, 2000). Budaya adalah hal paling mendasar yang menjadi penentu bagi keinginan dan perilaku seseorang dalam menentukan pilihannya pada produk dengan merek yang berebeda-beda.
Karakteristik atau cirri pribadi menjadi hal selanjutnya yang mempengaruhi keputusan pembelian, terutama usia dan tahapan dari siklus kehidupan pembeli, pekerjaan, kondisi ekonomi, gaya hidup, kepribadian dan konsep jati diri pembeli. Faktor psikologis utama juga menjadi hal yang berpengaruh terhadap pilihan membeli. Faktor pskologis utama tersebut diantaranya motivasi, persepsi, proses pembelajaran, juga kepercayaan dengan sikap.

Coffee shop merupakan suatu tempat yang identik dengan tatanan meja meja dan kursi yang rapi serta sofa yang nyaman menjual aneka variasi kopi dan makanan kecil sebagai pelengkap dan diiringi alunan musik yang menjadikan suasana nyaman yang dapat dirasakan konsumen (Kurniawan dan Sidiq, 2016). Usaha kedai kopi kini telah menjadi salah satu usaha yang menjanjikan. Model kedai kopi pun beragam, dari kedai kopi yang memberi kasan eksklusif atau mewah, sampai dengan kedai kopi yang terlihat standar. Dalam menjual produknya, kedaikedai tersebut memiliki spesifikasinya masing-masing. Usaha kedai kopi saat ini lahir menjadi usaha dengan berbagai konsep yang menarik, diantaranya konsep tempat, konsep pemasaran, konsep menu, konsep kemasan, dan konsep pelayanan. 
Situasi pada setiap kedai kopi dengan kekhasannya sendiri menjadi daya tarik tersendiri bagi konsumen.

Kalimera Coffee Bar adalah salah satu kedai kopi di Kota Salatiga yang menyajikan puluhan jenis menu minuman dan makanan. Minuman yang disajikan diantaranya: berbagai jenis kopi mulai dari Espresso Base yang terdiri dari empat varian rasa, Milk Espresso Based yang terdiri dari tujuh varian rasa, filter coffee yang terdiri dari enam varian rasa dan es kopi susu yang terdiri sari tujuh varian rasa. Selain kopi, Kalimera Coffee Bar ini juga menyajikan berbagai jenis minuman lain yang tidak mengandung kopi (non coffee) seperti chocolate yang memiliki enam varian rasa, tea yang memiliki enam varian rasa dan milk yang memiliki lima varian rasa. Selain minuman, Kalimera Coffee Bar juga menjual beberapa jenis makanan. Kedai kopi ini juga berlokasi cukup strategis sehingga mudah untuk dijangkau oleh konsumen dan memiliki banyak peminat, oleh karenanya peneliti tertatik untuk menganalisis perilaku konsumen terhadap keputusan pembelian kopi di Kalimera Coffee Bar.

Berdasarkan uraian diatas, maka dapat dirumuskan masalah dalam penelitian ini adalah: bagaimana karakteristik konsumen kopi di Kalimera
Coffee Bar, berapa indeks kepuasan konsumen terhadap atribut kopi di Kalimera Coffee Bar, dan atribut-atribut apa dari produk kopi yang dianggap penting oleh konsumen di Kalimera Coffee Bar? Sedangkan tujuan penelitian ini yaitu mengetahui karakteristik konsumen kopi di Kalimera Coffee Bar, menganalisis indeks kepuasan konsumen terhadap atribut produk kopi di Kalimera Coffee Bar dan menganalisis atribut-atribut produk kopi yang dianggap penting oleh konsumen di Kalimera Coffee Bar.

\section{METODE PENELITIAN}

Penelitian dilakukan bulan Oktober 2020 sampai November 2020 di Kalimera Coffee Bar Salatiga. Teknik pengambilan sampel yang dipakai dalam penelitian ini yaitu convenience sampling dengan jumlah sampel ditetapkan sebanyak 40 responden yang pernah membeli dan mengonsumsi kopi di Kalimera Coffee Bar. Teknik pengumpulan data dilakukan dengan metode wawancara, kuesioner yang diisi secara online, studi pustaka dan dokumentasi. Analisis data menggunakan metode analisis deskriptif, analisis Customer Satisfaction Index (CSI) dan analisis Importance and Performance Analysis (IPA). Data diolah menggunakan software Microsoft Office Excel 2007 dan SPSS versi 20 for windows. 


\section{Analisis Deskriptif}

Analisis deskriptif digunakan untuk menjelaskan karakteristik responden yang penah membeli dan mengonsumsi kopi di Kalimera Coffee Bar.

\section{Analisis Customer Satisfaction Index (CSI)}

Customer Satisfaction Index (CSI) arau indeks kepuasan konsumen dibutuhkan untuk dapat mengetahui nilai tingkat keouasan dari konsumen secara keseluruhan dengan meninjau tingkat kepentingan dari atribut-atribut produk kopi di Kalimera Coffee Bar. Langkahlangkah menghitung indeks kepuasan konsumen adalah:

1. Menghitung Weighting Factor (WF), yakni fungsi dari Mean Importance Score (MISi) dari masing-masing atribut dalam bentuk persen (\%) dari Total Importance Score (MISt) untuk semua atribut yang diuji.

$\mathrm{WF}=\frac{\mathrm{MISi}}{\mathrm{MISt}} \mathrm{x} 100$
2. Menghitung Weighted Score (WS), yakni fungsi dari Mean Satisfection Score (MSS) dikali dengan Weighting Factors (WF).

$\mathrm{WS}=\mathrm{MSS} \times \mathrm{WF}$

3. Menghitung Weighted Average Total (WAT) yaitu fungsi dari Total Weighted Score (WS) atribut ke-1 (a1) sampai atribut ke-8 (a8).

$\mathrm{WAT}=\mathrm{Wsa}_{1}+\mathrm{Wsa}_{2} \ldots . \mathrm{Wsa} 8$

4. Customer Satisfaction Index (CSI) atau indeks kepuasan konsumen adalah fungsi dari Weighted Avarage (WA) dibagi dengan Highest Scale (HS) (skala maksimum yang dipakai dalam penelitian ini adalah 5) dikalikan $100 \%$.

$\mathrm{CSI}=\frac{\mathrm{WA}}{\mathrm{HS}} \times 100$

Interpretasi nilai CSI dapat dilihat pada tabel 1.1.

Tabel 2.Interpretasi Customer Satisfactian Index (CSI)

\begin{tabular}{ll}
\hline Nilai CSI & Interpertasi \\
\hline $0<\mathrm{CSI} \leq 20 \%$ & Sangat tidak puas \\
$20 \%<\mathrm{CSI} \leq 40 \%$ & Tidak puas \\
$40 \%<\mathrm{CSI} \leq 60 \%$ & Cukup puas \\
$60 \%<\mathrm{CSI} \leq 80 \%$ & Puas \\
$80 \%<\mathrm{CSI} \leq 100 \%$ & Sangat puas \\
\hline
\end{tabular}

Sumber: Customer Satisfaction Index (Santoso, 2018) 
Analisis Importance and Performance Analysis (IPA)

Importance an Performance Analysis adalah sebuah teknik dalam mengukur atribut dari tingkat kepentingn (importance) dan tingkat kinerja (performance) yang gunanya untuk mengembangkan program pemasaran efektif. Metode atau teknik ini dipakai untuk dapat menganalisis tingkat kepentingan dan kinerja dari kepuasan konsumen (Supranto, 2006). Teknik Importace Performance Analysis dilakukan dengan cara memberikan kuesioner kepada responden untuk menilai tingkat kepentingan dan kinerja suatu organisasi.Kuesioner dicantumkan penilaian terhadap suatu organisasi dengan menggunakan skala likert. Skala likert yang digunakan pada penelitian ini menggunakan skala 5 yang mewakili penilaian bobot dari suatu atribut.

Kemudian hasil dari data yang diperoleh diolah dengan Importance Analysis Matrix. Importance Analysis Matrix adalah matrik yang menjelaskan perbandingan antara tingkat kepentingan dan kinerja melalui pembagian berdasarkan kuadran dari tiap atribut tersebut, yang dimana sumbu X merupakan sumbu yang mewakili persepsi konsumen terhadap kinerja sedangkn sumbu $\mathrm{Y}$ mewakili harapan konsumen. Pertama, menghitung nilai rata-rata dari persepsi konsumen terhadap tingkat kepentingan dan tingkat kinerja dari setiap atribut, dengan rumus persamaan berikut.

$$
X=\frac{\sum \mathrm{X} 1}{\mathrm{n}} ; Y=\frac{\sum \mathrm{Y} 1}{\mathrm{n}}
$$

Keterangan :

$X=$ Rata - rata skor tingkat kinerja

$Y=$ Rata - rata skor tingkat kepentingan

$n=$ Jumlah sampel yang digunakan

Kedua, menghitung rata - rata skor tingkat kepentingan dan kinerja dari setiap atribut. Nilai rata-rata tersebut digunakan sebagai batas dalam diagram kartesius. Berikut persamaan yang digunakan dalam menentukan batas diagram kartesius.

$$
\overline{\bar{X}}=\frac{\sum \mathrm{X} \overline{\overline{1}}}{\mathrm{k}} ; \overline{\bar{Y}}=\frac{\sum \mathrm{Y} \overline{\overline{1}}}{\mathrm{k}}
$$

Keterangan :

$\overline{\bar{X}}=$ Rata - rata skor tingkat kinerja seluruh atribut

$\overline{\bar{Y}}=$ Rata - rata skor tingkat kepentingan seluruh atribut

$k=$ Banyaknya atribut yang digunakan

Tahap terakhir, penjabaran hasil dari setiap atribut kedalam diagram kartesius. Berikut gambar kartesius dengan empat kuadran. 


\section{HASIL DAN PEMBAHASAN}

\section{Gambaran Umum Kalimera Coffee Bar}

Kalimera Coffee Bar merupakan kedai kopi siap saji di kota Salatiga yang berdiri pada gelombang keempat industri warung kopi di Indonesia. Kedai kopi ini berlokasi di Jalan Seruni No. 7, Siderejolor, Salatiga, Jawa Tengah 50714. Kedai kopi ini sudah mulai dikenal banyak orang, karena merupakan salah satu kedai kopi yang pertama hadir di Salatiga sejak awal kopi mulai banyak diminati oleh berbagai kalangan. Kedai kopi Kalimera Coffee Bar didirikan pada tahun 2016 oleh Bayu Prasetyo Aji dan dikelola langsung oleh pemiliknya.

\section{Gambaran Umum Responden}

Karakteristik umum dari konsumen usia, jenis kelamin, status pernikahan, pendidikan, pekerjaan, dan pendapatan per bulan. Dari hasil penelitian dengan 40 responden, mayoritas konsumen kopi di Kalimera Coffee Bar yang berada di rentang usia $21-25$ tahun dengan persentase $52,5 \%$ berjenis kelamin perempuan sebanyak $52,5 \%$ dan laki-laki sebanyak $47,5 \%$ semuanya berstatus belum menikah dengan tingkat pendidikan Diploma/ Sarjana (S1, S2, S3) sebanyak $55 \%$, mayoritas masih berstatus sebagai pelajar atau mahasiswa sebanyak $60 \%$ dan berpanedapatan dibawah Rp. 2.500.000.

\section{Analisis Customer Satisfaction Index (CSI)}

Analisis CSI digunakan untuk mengetahui indeks atau tingkat dari kepuasan konsumen kopi di Kalimera Coffee Bar secara menyeluruh. Berdasarkan hasil perhitungan kepuasan konsumen kopi di Kalimera Coffee Bar salatiga, diketahui bahwa nilai CSI atau indeks kepuasan konsumen adalah sebesar $87,39 \%$. Nilai ini berkisar pada skala antara 80 - 100 yang berarti konsumen dapat dikatakan sangat puas pada pembeliannya di Kalimera Coffee Bar.

Tabel 3. Perhitungan Customer Satisfaction Index (CSI) di Kalimera Coffee Bar Salatiga

\begin{tabular}{lcccc}
\hline \multicolumn{1}{c}{ Atribut } & $\begin{array}{c}\text { Mean Importance } \\
\text { Score } \text { (MIS) }\end{array}$ & $\begin{array}{c}\text { Mean Satisfaction } \\
\text { Score } \text { (MSS) }\end{array}$ & $\begin{array}{c}\text { Weight Factors WF } \\
\text { (MIS/Total MIS) }\end{array}$ & $\begin{array}{c}\text { Weight Score WS } \\
\text { (WF x MSS) }\end{array}$ \\
\hline Rasa & 4.73 & 4.55 & 13.61 & 61.91 \\
Varian rasa & 4.18 & 4.23 & 12.02 & 50.80 \\
Aroma & 4.30 & 4.23 & 12.38 & 52.32 \\
Ukuran/ Volume isi & 3.95 & 4.20 & 11.38 & 47.78 \\
Tampilan fisik & 3.93 & 4.28 & 11.30 & 48.32 \\
Kualitas pelayanan & 4.78 & 4.60 & 13.75 & 63.25 \\
Kenyamanan tempat & 4.75 & 4.63 & 13.68 & 63.26 \\
Harga produk & 4.13 & 4.15 & 11.88 & 49.30 \\
Jumlah & 34.73 & & WT & 436.94 \\
CSI & & & $87.39 \%$ & \\
\hline
\end{tabular}


Analisis Importance and Performance

yang perlu diperhatikan oleh pihak Analysis (IPA)

Kalimera Coffee Bar untuk

Analisis Importance and Performance membandingkan harapan dan kinerja Alnalysis (IPA) bertujuan untuk atribut produk menggunakan diagram mengetahui atribut-atribut dari produk kopi kartesius.

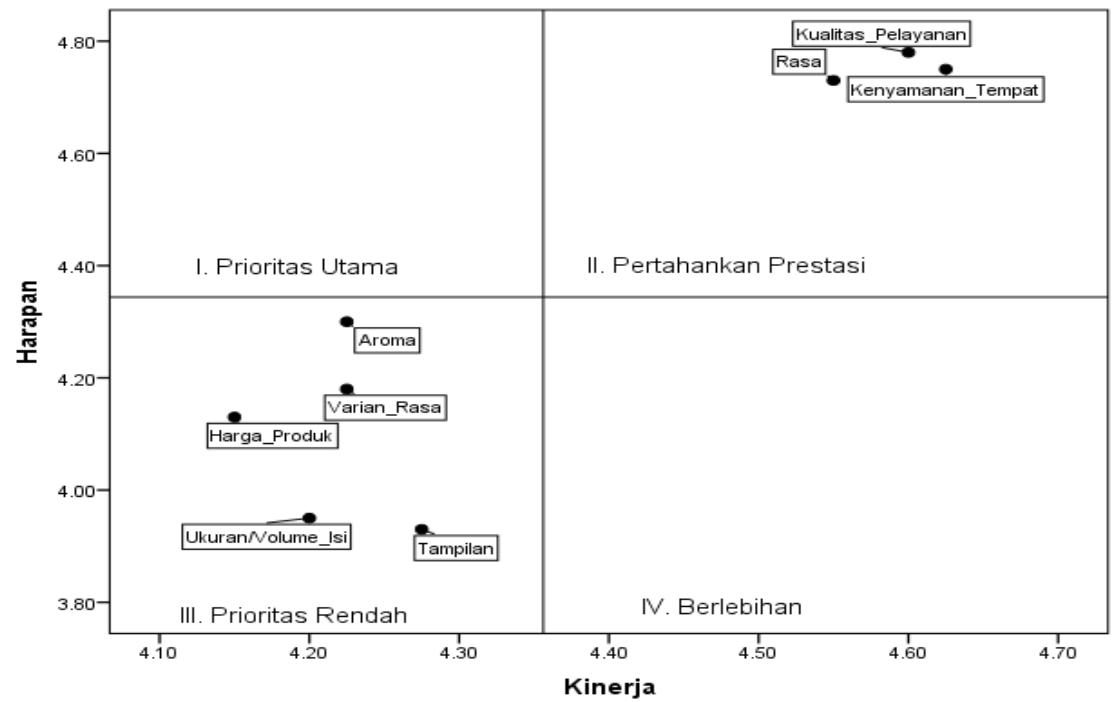

Gambar 1. Diagram Kartesius Hasil Importance and Performance Analysis

Kuadran I (Prioritas Utama) pada diagram kartesius menunjukkan tingkat kepentingan dari suatu atribut produk yang dianggap sangat penting oleh konsumen, tetapi kinerja yang ditunjukkan oleh atribut ini dianggap masih rendah atau belum maksimal. Berdasarkan hasil penelitian, tidak terdapat atribut produk pada kuadran I. Artinya, tidak ada dari atribut produk yang diinginkan dari responden yang tidak atau belum dipenuhi oleh Kalimera Coffee Bar atau dapat dikatakan tidak ada produk yang dirasa mengecewakan oleh konsumen.

Kuadran II (Pertahankan Prestasi) merupakan kuadran yang memuat atribut- atribut yang dianggap penting oleh konsumen dan kinerja dari atribut-atribut tersebut sudah sesuai harapan konsumen (konsumen menilai tingkat kinerjanya baik). Atribut-atribut dari produk kopi di Kalimera Coffee Bar yang berada pada kuadran ini adalah kualitas pelayanan, rasa dan kenyamanan tempat. Atribut-atribut dalam kuadran ini harus tetap dipertahankan oleh Kalimera Coffee Bar sebab variabel-variabel tersebut membuat produk terlihat unggul di mata responeden.

Kuadran III (Prioritas Rendah) pada diagram kartesius menggambarkan atribut-atribut yang dianggap kurang penting oleh konsumen dan tingkat kinerja 
pada kenyataanya tidak terlalu baik. Atribut-atribut pada kuadran ini adalah aroma, varian rasa, harga produk, ukuran/ volume isi, dan tampilan fisik kopi.

Kuadran IV (Berlebihan) adalah kuadran yang berisikan atribut-atribut yang menurut konsumen dianggap kurang penting, tapi tingkat kinerja yang diberikan dari atribut dirasa berlebihan. Berdasarkan gambar 1, tidak terdapat atribut produk pada kuadran IV. Artinya, dari pihak kafe tidak ada yang berlebihan dalam menyajikan produknya.

\section{KESIMPULAN DAN SARAN}

\section{Kesimpulan}

Karakteristik konsumen kopi di Kalimera Coffee Bar adalah perempuan dan laki-laki, berumur remaja sampai dewasa (16 sampai 40 tahun), berstatus belum menikah dengan tingkat pendidikan SMA dan Diploma/ Sarjana (S1, S2, S3), didominasi oleh pelajar dan mahasiswa dan sisanya berprofesi sebagai pegawai swasta, PNS/ ABRI, wiraswasta dan freelancer, dengan pendapatan per bulan dibawah Rp. 2.500.000 sampai dengan diatas $\mathrm{Rp}$. 5.000.000. Nilai indeks kepuasan konsumen terhadap atribut produk kopi di Kalimera Coffee Bar yang telah dihitung dengan analisis CSI adalah sebesar 87,39 $\%$ yang berarti konsumen sangat puas terhadap atribut-atribut produk kopi yang disajikan di Kalimera Coffee Bar. Atributatribut produk yang perlu dipertahankan terdapat pada kuadran II (kualitas pelayanan, rasa dan kenyamanan tempat).

\section{Saran}

1. Disarankan pihak Kalimera Coffee Bar untuk dapat mempertahankan atributatribut produk yang sudah baik kinerjanya dan terus melakukan perbaikan terhadap atribut-atribut yang masih kurang menurut anggapan konsumen agar dapat menambah kepuasan konsumen.

2. Disarankan kepada pemerintah untuk mendukung perkembangan usaha kedai kopi yang ada di Kota Salatiga.

3. Bagi peneliti berikutnya disarankan untuk melakukan penelitan mengenai laoyalitas konsumen pada kedai kopi.

\section{DAFTAR PUSTAKA}

Kotler, p., dan A. B. Susanto. 2000. Manajemen Pemasaran di Indonesia, Edisi Pertama. Jakarta: Salemba Empat.

Kurniawan, A. 2017. Perilaku Konsumtif Remaja Penikmar Warung Kopi. Surakarta: Universitas Sebelas Maret.

Kurniawan, A., dan Sidiq, S. S. 2016. Penerapan Personal Hygiene Pada Karyawan Food and Beverage Service Hotel Aryaduta Pekanbaru. (Doctoral dissertation, Riau University). 
Pusat Data dan Sistem Informasi Pertanian. 2016. Outlook Kopi. http://epublikasi.setjen.pertanian.go.i d/. Diunduh 23 Oktober 2020.

Raharjo, P. 2012. Kopi. Jakarta: Penebar Swadaya.
Santoso, S. 2018. Menguasai Statistik dengan SPSS 25. Jakarta: PT Elex Media Komputindo.

Supranto. 2006. Pengukuran Tingkat Kepuasan Pelanggan. Jakarta: Rineka Cipta 